
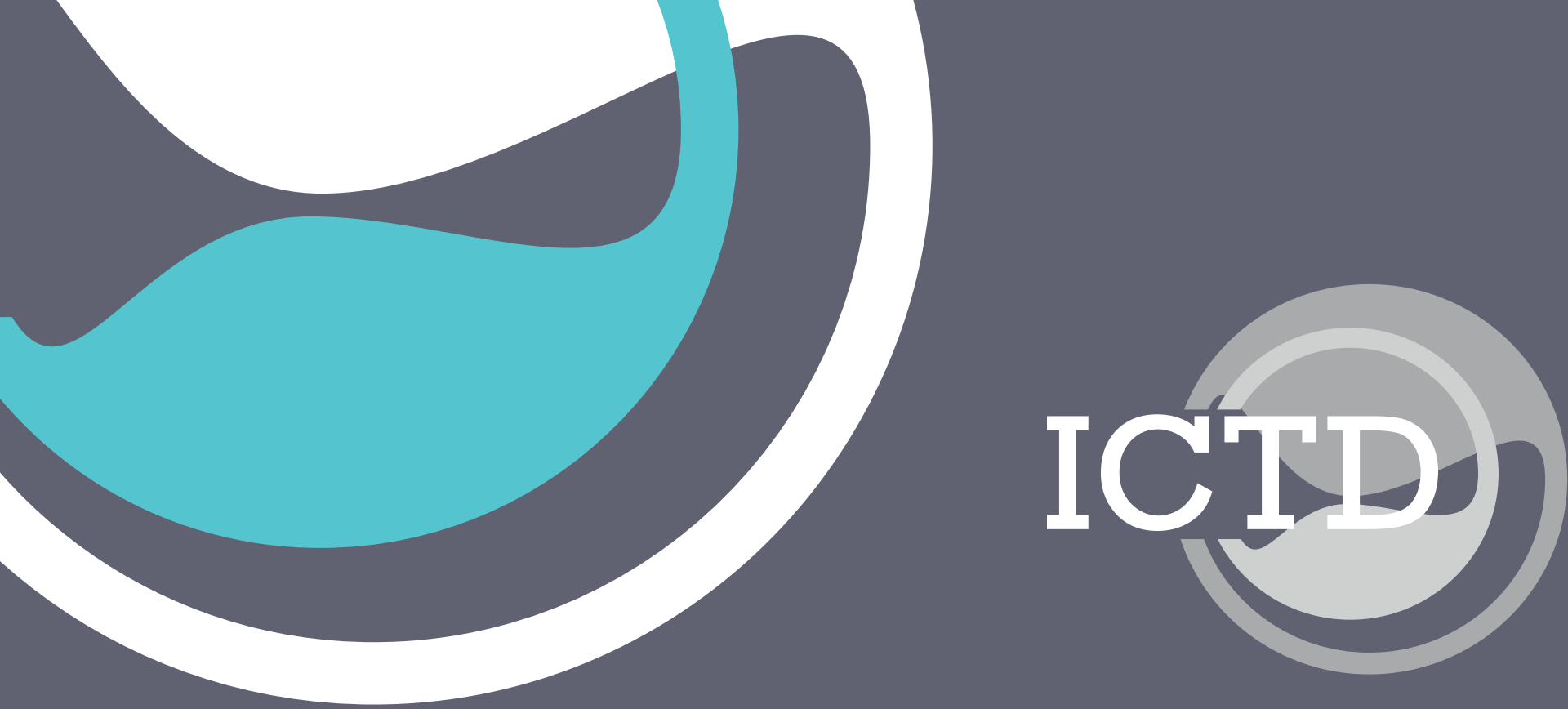

Working Paper 131

\title{
Beyond Greed: Why Armed Groups Trax
}

Tanya Bandula-Irwin, Max Gallien, Ashley Jackson, Vanessa van den Boogaard, and Florian Weigand November 2021

fol Centre for the Study BILL \& MELINDA of Armed Groups
GATES foundation institute of
development
studies

NR UKaid 
ICTD Working Paper 131

\section{Beyond Greed: Why Armed Groups Tax}

Tanya Bandula-Irwin, Max Gallien, Ashley Jackson, Vanessa van den Boogaard, and Florian Weigand

November 2021 
Beyond Greed: Why Armed Groups Tax

Tanya Bandula-Irwin, Max Gallien, Ashley Jackson, Vanessa van den Boogaard, and Florian Weigand ICTD Working Paper 131

First published by the Institute of Development Studies in November 2021

(C) Institute of Development Studies 2021

ISBN: [978-1-78118-868-2]

DOI: $\underline{10.19088 / I C T D .2021 .021}$

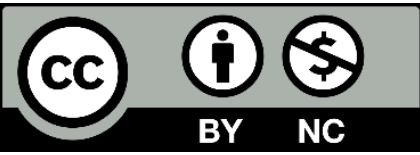

This is an Open Access paper distributed under the terms of the Creative Commons Attribution Non Commercial 4.0 International license, which permits downloading and sharing provided the original authors and source are credited - but the work is not used for commercial purposes. http://creativecommons.org/licenses/by-nc/4.0/legalcode

Available from:

The International Centre for Tax and Development at the Institute of Development Studies, Brighton BN1 9RE, UK Tel: +44 (0) 1273606261

Email: info@ictd.ac

Web: www.ictd.ac/publication

IDS is a charitable company limited by guarantee and registered in England

Charity Registration Number 306371

Charitable Company Number 877338 


\title{
Beyond Greed: Why Armed Groups Tax
}

\author{
Tanya Bandula-Irwin, Max Gallien, Ashley Jackson, Vanessa van den \\ Boogaard, and Florian Weigand
}

\section{Summary}

Armed groups tax. Journalistic accounts often include a tone of surprise about this fact, while policy reports tend to strike a tone of alarm, highlighting the link between armed group taxation and ongoing conflict. Policymakers often focus on targeting the mechanisms of armed group taxation as part of their conflict strategy, often described as 'following the money'. We argue that what is instead needed is a deeper understanding of the nuanced realities of armed group taxation, the motivations behind it, and the implications it has for an armed group's relationship with civilian and diaspora populations, as well as the broader international community. This paper builds on two distinct literatures, on armed groups and on taxation, to provide the first systematic exploration into the motivation of armed group taxation. Based on a review of the diverse practices of how armed groups tax, we highlight that a full account of their motivation needs to go beyond revenue collection, and engage with key themes around legitimacy, population control, institution building, and the performance of public authority. We problematise common approaches towards armed group taxation and state-building, and outline key questions of a new research agenda.

Keywords: armed groups, taxation, informality, conflict, state-building

Tanya Bandula-Irwin is a PhD student at the University of Toronto. Her dissertation focuses on civilian-armed group dynamics surrounding taxation, with a focus on the Philippines. She is a Fellow at the Trudeau Centre for Peace, Justice and Conflict, a Junior Fellow with the Defense and Security Foresight Group, and Vice-President of Women in International Security-Canada, Toronto.

Max Gallien is a Research Fellow at the Institute of Development Studies and the International Centre for Tax and Development, where he co-leads the research programme on informality and taxation as well as the centre's capacity building programme. A political scientist, he specialises in the politics of informal and illegal economies, the political economy of development and the modern politics of the Middle East and North Africa. He is also a Senior Fellow at the Global Initiative against Transnational Organised Crime and the co-editor of the Routledge Handbook of Smuggling (Routledge, 2021).

Ashley Jackson is the Co-Director of the Centre for the Study of Armed Groups at ODI. She has conducted extensive research on and with the Taliban and civilians living under their control in Afghanistan. She has also conducted on the ground research and dialogue with armed groups in an array of other contexts, from Central African Republic to Iraq. Her research on armed groups began as a Research Fellow with the Humanitarian Policy Group at ODI, where she led a multi-year project on humanitarian dialogue with armed groups in Afghanistan, Somalia, Sudan, and South Sudan. She is the author of Negotiating Survival: Civilian-Insurgent Relations in Afghanistan (Hurst, 2021).

Vanessa van den Boogaard is a Research Fellow at the International Centre for Tax and Development, where she co-leads the research programme on informality and taxation and leads the research programme on the role of civil society and tax. Her research focuses on informal taxation and revenue generation, with a particular focus on taxation, informality, and 
state-building in conflict-affected contexts. She has research experience in Somalia, the Democratic Republic of the Congo and Sierra Leone.

Florian Weigand is the Co-Director of the Centre for the Study of Armed Groups at ODI and a Research Associate at the London School of Economics and Political Science. His work focuses on armed groups, illicit economies and international interventions and explores the politics and societal dynamics of conflict zones, borderlands, and other complex

environments. He has conducted extensive research in South Asia and Southeast Asia and is the author of Waiting for Dignity: Legitimacy and Authority in Afghanistan (Columbia University Press, 2022) and Conflict and Transnational Crime: Borders, Bullets \& Business in Southeast Asia (Edward Elgar, 2020) and the co-editor of the Routledge Handbook of Smuggling (Routledge, 2021). 


\section{Contents}

Summary 3

Acknowledgements $\quad 6$

Acronyms $\quad 6$

$\begin{array}{lr}\text { Introduction } & 7\end{array}$

$1 \quad$ Armed group taxation, revenue and conflict 9

2 Beyond revenue: the multifaceted motivations for armed group taxation 11

$\begin{array}{ll}2.1 \text { Ideology } & 11\end{array}$

$2.2 \quad$ Building legitimacy 13

$2.3 \quad$ Institution building 14

$\begin{array}{ll}2.4 & \text { Legibility and control of civilian populations } \\ & 16\end{array}$

$\begin{array}{ll}2.5 & \text { Performing public authority } \\ & 18\end{array}$

3 Conclusions 21

$\begin{array}{lll}\text { Appendix } \quad \text { List of cases included in this review } & \mathbf{2 4}\end{array}$

$\begin{array}{ll}\text { References } & 26\end{array}$ 


\section{Acknowledgements}

This paper was made possible through a partnership between the ICTD and the Centre for the Study of Armed Groups at the Overseas Development Institute. The authors would like to thank Hazel Granger and the anonymous reviewers for their very helpful feedback and comments.

\section{Acronyms}

$\begin{array}{ll}\text { ADF } & \text { Allied Democratic Forces } \\ \text { AQIM } & \text { Al-Qaeda in the Islamic Maghreb } \\ \text { BAAD } & \text { 'Big, Allied and Dangerous' } \\ \text { CAR } & \text { Central African Republic } \\ \text { CPP-NPA } & \text { Communist Party of Philippines - New People's Army } \\ \text { DRC } & \text { Democratic Republic of the Congo } \\ \text { GAM } & \text { Free Aceh Movement or Gerakin Aceh Merdeka } \\ \text { HTS } & \text { Hay'at Tahrir al-Sham } \\ \text { JNIM } & \text { Jama'at Nasr al-Islam wal Muslimin } \\ \text { KIO/A } & \text { Kachin Independence Organisation/Army } \\ \text { KNLA } & \text { Karen National Liberation Army } \\ \text { KNU } & \text { Karen National Union } \\ \text { MILF } & \text { Moro Islamic Liberation Front } \\ \text { MNLF } & \text { Moro National Liberation Front } \\ \text { MUJAO } & \text { Movement for Oneness and Jihad in West Africa } \\ \text { NDA-K } & \text { New Democratic Army - Kachin } \\ \text { UN } & \text { United Nations } \\ \text { UPC } & \text { Union for Peace in the Central African Republic } \\ \text { USD } & \text { US Dollar }\end{array}$


In downtown Myitkyina, small shops pay a tax of around MMK 1 million [c. US\$720] to the KIO/A per year. But it's not done very systematically. Sometimes they come twice per year, sometimes once per year. Private car owners have to pay at checkpoints. If they give you a receipt, you can use it for a year. But if you have a receipt from the $K I O / A$ and the government finds it, you may get arrested. And the government is collecting taxes too. So most people in the city pay to the KIO/A and the government. Resident of (government-controlled) Myitkyina, Myanmar, 7 January 2018

The Taliban tax everything. They get money from the vehicles that cross the district or are going from one district to another. They collect tax on the crops of the farmers, which is called Usher... I give my Zakat and Usher to them too. Resident of Pashtunkot District, Faryab Province, Afghanistan, 17 February 2019

\section{Introduction}

Armed groups tax. Almost one third of the 'violent non-state organizations' included in the 'Big, Allied and Dangerous' (BAAD) Dataset participated in some form of resource collection from businesses or communities, and Albert (2020) finds that civilian taxation is the most prevalent governance activity in the Rebel Quasi-State Institution Dataset (Walsh, Conrad and Whitaker 2018; Albert 2020: 15). Journalistic accounts often include a tone of surprise about both this fact and the effectiveness of some armed groups' taxing practices, marvelling, for instance, that 'Al-Shabab "collects more revenue than government"' (Harper 2020) or examining 'How ISIS Is Using Taxes to Build a Terrorist State' (Thorndike 2014). At the same time, policy reports tend to strike a tone of alarm, highlighting the link between armed group taxation and ongoing conflict (e.g. Keatinge 2014; Lister 2014; Okello 2020). As described by Di Cosmo, Fassin and Pinaud (2021: 8) 'Because the collection of revenues is supposed to be the exclusive prerogative of the state, when a non-state group begins to tax the citizens living on territories nominally under a state's sovereignty, such an action is regarded by most analysts as both illegal and illegitimate, that is, mere extortion' (see also Mampilly 2021). Following from this, policymakers tend to focus on targeting the mechanisms of armed group taxation as part of their conflict strategy, often described as 'following the money' (Croissant and Barlow 2007). As responses to the potential ramifications of armed group taxation, however, shock and awe are insufficient, often not leading to deeper attempts to understand the nuanced and diverse realities of armed group taxation, the motivations behind it, and the implications it has for an armed group's relationship with civilian and diaspora populations, as well as the broader international community.

In this paper, we explore the central question of why armed groups tax. ${ }^{1}$ While there has been increasing scholarly and policy attention to how non-state armed groups finance themselves, less attention has been given to the motivations behind different armed group revenue generation strategies. Though a growing body of academic work engages with the politics and motivations of armed group taxation (Revkin 2020; Sabates-Wheeler and Verwimp 2014; Mampilly and Thakur forthcoming; Mampilly 2021), many policy analysts continue to assume that armed groups are driven purely by revenue motivations, reflecting longstanding assumptions about the role of 'greed' in driving conflict. Indeed, Mampilly (2021: 77) notes that the dominant paradigm in studying armed group taxation is undergirded by 'the belief that rebels only engage in taxation to generate revenue'. These ideas of economic determinism, however, often lack nuance, and fail to capture the diversity and breadth of the motivations leading armed groups to levy taxes on civilian populations.

Following conventional understandings, we define armed groups as (i) armed organisations willing and capable of using violence in pursuit of their objectives that are (ii) not fully integrated into formalised state institutions such as regular armed, presidential guards, police or special forces (Berti 2016; Hofmann and Schneckener 2011). 
At the same time, the limited academic literature that exists tends to focus on evidence from single case studies, while including a bias towards taxation of elites rather than broader civilian populations (Mampilly 2021: 86). A central contribution of this paper is in bringing together and reviewing disparate case studies and anecdotal accounts of wide-ranging types of armed group taxation to illustrate both the diversity of the motivations underpinning the revenue generation strategies of armed groups and to identify themes and patterns that emerge across diverse contexts. To do so, we have systematically reviewed scholarly, policy, and journalistic accounts of the taxation strategies of 41 armed groups across diverse geographical contexts and reflecting considerable variation in the ways groups collect taxes, if at all. ${ }^{2}$ Our empirical strategy is explicitly exploratory - it is not intended to show the relative frequency of particular tax arrangements or highlight statistically significant patterns. Instead, we review diverse cases of armed group tax arrangements to inductively draw inferences about the diversity of motivations that underly them.

Unsurprisingly, the meaning of taxation in relation to armed groups is complex and contested. Revenue extraction exists on a spectrum ranging from 'simple plunder, to protection rackets, to the material reciprocation of the recognition of rights' (Hoffmann, Vlassenroot and Marchais 2016: 1434). While we further reflect on these conceptual challenges in the conclusion, we approach armed group taxation with the recognition that revenue extraction by armed groups is embedded in social institutions and exists on a spectrum of authority, ranging from coercive to consensual, with some forms of extraction looking more like state-like taxation and others looking more like extortion. We follow scholars of rebel governance in distinguishing informal taxation and revenue generation from corruption and extortion by emphasising taxation's foundation in 'publicly known rules and procedures' while being justified on public interest grounds (Revkin 2020). ${ }^{3}$

Through this exploration, we illustrate that armed group taxation is not only driven by economic motives. We argue for greater nuance in the analysis of revenue collection by armed groups and show that motivations for taxation are multifaceted. No single motive whether revenue, ideology, control, legitimacy, institution- or state-building - can alone provide a sufficient account of why armed groups tax. As with state taxation, taxation by armed groups relates to a broad set of political motivations and strategic interests and can enable multiple interrelated outcomes. Taxation underpins organisational capacity and the capacity to wage conflict but is also central to the relationship between armed groups and local populations and the logics of internal organisation and institutional structure.

Meanwhile, the motivations for armed group taxation are deeply intertwined with the broader objectives of the group. Armed groups may pursue a diversity of objectives, ${ }^{4}$ which may

2 We examined 41 cases of armed groups, the majority of which engaged in some form of levying taxes, though some groups that did not appear to tax were also included. For each group, we reviewed types of taxes collected; taxed constituencies; group characteristics like goals, ideology, age, and size; relationships to the state; tax collection mechanisms; compliance mechanisms; other non-tax sources of revenue; and use of tax, including goods or services rendered in exchange for tax revenue. The cases include groups that were founded from 1949-2012, with the exception of Camorra which is estimated to have been founded in the $17^{\text {th }}$ century, though is still active today. We also included additional case examples, drawn from previously published work. For a list of all cases included in this paper, please see the appendix.

3 Revkin (2020) notes that tax-like payments are 'justified on public interest grounds (financing public goods, paying for the costs of war, redistributing assets from rich to poor) whereas theft is justified only by a self-serving desire for private gain'. Rules, meanwhile, may be publicly known through written documentation - for instance, Richani (2013: 68) describes how the FARC has applied written codes of taxation since 1996 - as well as through oral or other social channels. In explaining how the tax policies of the Maoist insurgency in eastern India differed from organised crime, for example, a Maoist rebel official clarified that, 'This is not corruption. This is taxation... We have rules and norms around how we tax people... We also have rules and norms around how we use the fund[s] collected. So we are not simply collecting money for private gain - that would be corruption' (cited in Chakravarti 2014: 150). Some scholars nevertheless describe this as 'institutionalized' extraction (Sabates-Wheeler and Verwimp 2014).

$4 \quad$ For instance, groups can pursue economic and political goals, such as leftist, ethno-nationalist or religious based desires for a change in the status quo. These goals may also be more specific, like the toppling of an incumbent leader or regime or the establishment of a de facto or proto-state. More specifically, objectives may include (1) secession/independent state; (2) increased autonomy within state; (3) regime change; (4) pursuit of improved group 
change over time, and which may be pursued through a wide range of strategic and operational dimensions, of which taxation can be an important one.

As the remainder of this paper argues, taxation certainly provides material resources for armed groups and some groups are likely primarily motivated by revenue concerns.

However, taxation also reinforces ideology, builds legitimacy with civilian populations, builds institutions that enable various objectives (including but not limited to increased autonomy or secession), serves as a way to control and administer populations, and acts as a key way to perform and project public authority. In the rest of the paper, we outline the various ways in which taxation serves a strategic purpose for armed groups - to unpack why they tax and how tax relates to their institutional structure and relationships with civilians. ${ }^{5}$

In drawing attention to the ways in which armed groups tax for more than revenue purposes, we complicate theories of taxation and state-building. In considering armed group taxation we advise against a deterministic or teleological approach that assumes a link between the mechanisms of taxation and the institutional forms that armed groups are working towards. While the taxing motivations of armed groups are thus deeply linked to their objectives, this relationship is not always purely material, teleological or focused only on stated or long-term objectives.

We conclude by highlighting the policy implications of the multifaceted motivations for armed group taxation, identifying remaining knowledge gaps in understanding armed group taxation, and suggesting questions for a new research agenda on armed group taxation.

\section{Armed group taxation, revenue, and conflict}

Among the most obvious reasons why armed groups engage in taxation is to secure revenue to support their operational objectives, sustain their survival, or secure profits. Over the past two decades, the opportunity for material gains has been the most popular framework to understand rebel taxation practices, influenced by theories of the ways in which greed influences broader conflict motivations (Collier and Hoeffler 2004). Shaped by the ideas of Collier and Hoeffler, armed groups came to be viewed as quasi-criminal, profit-motivated actors (Mampilly 2021: 78). Indeed, views on taxation in conflict-affected areas 'were dominated by the "greed'"' literature of the early 2000 s, which largely framed taxation during conflict as predatory and violent' and primarily driven by the motivation to increase revenue (Hoffmann et al. 2016: 1435). Metelits (2009), for instance, argues that resource maximisation is the dominant driver of rebel group behaviours, ${ }^{6}$ while the literature on war economies has frequently emphasised that conflicts can be fuelled by armed groups' desire for revenue expansion, for instance, by competing for control over natural resources (Le Billion 2006; Rettberg and Ortiz-Riomalo 2016) and foreign aid (de Waal 1997; Keen 2008).

In some cases, revenue indeed appears to drive some taxing behaviours of armed groups. Taxation can be incredibly lucrative for armed groups, with taxation practices allegedly accounting for the majority of revenue for some of the largest armed groups globally, including al-Shabaab, Boko Haram, FARC, HTS, JNIM, ISIS, the Taliban, and armed actors

rights; (5) pursuit of improved political representation or participation; (6) remove current leader; (7) democratisation; (8) leftist revolution; (9) implement theocracy; and (10) implement military regime (see Braithwaite 2009; San-Acka 2015).

$5 \quad$ Naturally, it is difficult to judge the exact intentions and motivation of an armed group, especially when considering that their policies often are the result of competing interests, ideas, and sources of power within each armed group. Hence, the paper relies on an observation and analysis of the practices of armed groups.

$6 \quad$ Specifically, they argue that insurgents restrain their violence against civilians so long as they maintain a monopoly on the control of resources, but if they face competition over this control, these groups will abruptly adopt more coercive tactics in pursuit of material gains 
in the DRC (Nellemann, Henriksen, Pravettoni, Schlingemann, Shaw and Reitano 2018). Estimates of tax revenues for these groups are in the tens of millions, with al-Shabaab, for example, allegedly earning between US\$38-56 million at their height of tax collection in 2012; armed groups in the DRC having been estimated to make between US $\$ 14$ and US $\$ 50$ million annually on illicit charcoal taxes; and ISIS' tax revenue often estimated to out-perform resource revenues, with tax revenue estimated to be between US\$300-400 million and oil and gas revenue estimated to be between US\$150-450 in the years 2014-2017 (Nellemann et al. 2018). ${ }^{7}$ Given the revenue potential of these taxing activities, it is therefore no surprise that armed groups establish extensive and robust taxing practices.

Mirroring broader arguments about the relationship between taxation and resource rents (Collier and Hoeffler 2005), groups have also been shown to establish taxation practices when given lucrative opportunities. ${ }^{8}$ Specifically, the presence of natural resources can amplify the economic incentives to tax, given the possibilities for taxing wealthy resource companies and/or the highly valuable goods entering or exiting a given area. Taxing the production, movement, and sale of natural resources is a common taxing activity of armed groups. Armed groups have even shown a willingness to fight over control of trade routes for their tax revenue potential, such as in the CAR (Jaillon, Schouten and Kalessopo 2017) and Somalia (Ahmad 2017). In cases where groups are actively competing for control over natural resources or the ability to tax lucrative natural resources, revenue appears to be at least one motivating factor for taxation.

The costs of war-making are also often seen as a driver of taxation. Identified in both analyses of contemporary conflict and historical accounts of conflict and state formation (Darling 1996; Elias 1994; Tilly 1985; Xu and Xu 2016), this logic may be extended to the financing of conflict by armed groups. For instance, Elias (1994) notes that in early modern Europe, feudal rulers realised that instead of relying on vassals for military service, building large infantries helped to win wars, but required centralised revenue generation. Similarly, Tilly (1990: 15) describes, 'War and the preparation for war involved rulers in extracting the means of war from others who held the essential resources... and who were reluctant to surrender them without strong pressure or compensation.' In Tilly's seminal argument, warmaking requires first the elimination of internal enemies, then protection from external enemies, and finally revenue extraction from civilians by way of taxes in order to fund these protection activities (Tilly 1985). Likewise, Darling (1996) shows how tax collection in the Ottoman Empire during the Ottoman-Habsburg wars strengthened the Ottomans' administrative capacity, and contributed to early state formation (Darling 1996). In a more recent example, $\mathrm{Xu}$ and $\mathrm{Xu}$ (2016) also show how conflict enabled the expansion of taxation by the Nationalist Government in China from 1927-1937 and 1946-1949, which led to increases in state revenue and, accordingly, state capacity (Xu and Xu 2016). As it did in these representations of state formation, taxation provides one way in which contemporary armed groups raise revenue to support the costs of war-making. Revenue motivations are clearly central to understanding armed group taxation. They do not, however, explain the full picture, as we illustrate below.

We recognise here that these estimates are likely rough, as it is difficult to come across verifiable resource estimates in many cases of armed non-state actor revenue.

$8 \quad$ This is in line with Weinstein (2007), who shows that resource availability shapes how armed groups interact with civilians. 


\section{Beyond revenue: the multifaceted motivations for armed group taxation}

While material incentives thus help explain at least some taxing behaviours of armed groups, this does not explain why armed groups tax even when it is not a lucrative option. While some taxing endeavours prove to be exceptionally lucrative - including, for example, the taxation of construction, resource extraction, or trade - taxing civilians is not always so profitable. In some cases, collected revenues do not cover the cost of collection. For example, in Afghanistan, A. Jackson (2018: 23) shows how the Taliban often collects small amounts from households for electricity that are not necessarily enough to cover the costs of electricity production, but rather 'what they estimate is fair'. Similarly, Mampilly (2021: 86) notes that the levying of 'token' or 'head' taxes on low-income groups is 'surprisingly commonplace', despite the minimal revenues and revenue inefficiency implied by such types of taxes (see also van den Boogaard and Beach forthcoming). At the same time, armed groups tax civilians even where more lucrative sources of revenue are available. For example, rather than derive profits from the illicit heroin and opium trade, the $\mathrm{KIO} / \mathrm{A}$ taxes civilians through a tax on shops and vehicles (Weigand 2020), while in Pakistan, the Tehrik-iTaliban (TTP) collects significant revenues through the taxation of the trade of goods, including narcotics, and construction projects, but also charges civilians a comparatively small residence tax of USD 2 per month (Acharya, Bukhari and Sulaiman 2009). ${ }^{9}$

These examples suggest that revenue is not the sole motivation behind the taxing activities of armed groups. While material incentives tell part of the story of why armed groups tax, a revenue-based explanation needs to be supplemented with a wider view of what taxation can 'do' for armed groups (Mampilly 2021). In addition to revenue, we consider in turn five interrelated and non-mutually exclusive explanations for armed group taxation, showing how tax may be a means of achieving ideological aims, building legitimacy, institution building, imposing control and legibility over territory and populations, and performing public authority with the aim of gaining credibility as a state-like entity.

\subsection{Ideology}

Compared to revenue, ideology is a comparatively understudied factor influencing rebel revenue collection practices. Yet, few groups present themselves as being driven by 'greed' - instead, justifications for actions are typically framed with reference to objectives like nationalism, religious purity, or a revolutionary agenda. Ideological taxation may be seen to serve two main functions for rebel groups: an instrumental one, with taxation instilling behavioural bounds, erasing individuality and establishing a group identity that enables cohesion, and a normative one, with taxation helping to define acceptable behaviours and boundaries (Sanín and Wood 2014). Within the realm of normativity, ideology shapes how rebel groups derive policy and practice and their means of justifying those practices both internally and externally.

There are clear indications that ideology shapes how revenue is collected and how these practices are rationalised across diverse contexts. Among Islamist movements, for example, taxation is often framed in Islamic tenets and language. In areas of Afghanistan under Taliban control, taxes are often framed as ushr (commonly interpreted as an Islamic annual

Civilian taxation is similarly prevalent in other contexts where, despite the availability of natural resources, illicit economic activities, the option to tax large businesses and traders, and other spoils of war, armed groups continue to tax civilians. Other examples where civilian taxation is prevalent despite the availability of other non-tax sources of finance include the CPP-NPA and MILF in the Philippines, the LTTE in Sri Lanka, and both the ELN and FARC in Colombia. 
tax on land or whatever produce or harvest is being brought to market) or zakat (obligation on Muslims to donate 2.5 per cent of their disposable income to the poor). The payment of zakat, one of the five pillars of Islam, is framed as not only being about obeying the Taliban, but about being a good Muslim, irrespective of the fact that zakat is rarely actually redistributed as charity by the Taliban (A. Jackson 2018). Meanwhile, some armed groups link taxation to their revolutionary ideology, as with the Shining Path's tax cupos revolucionarios (revolutionary quota) in Peru and the NPA's revolutionary tax in the Philippines (Quimpo 2014).

Ideology is also instrumentalised through taxation in order to define undesirable behaviours or to compel civilians to demonstrate compliance with certain norms. For instance, socialist groups may tax luxury goods and business elites, such as the CPP-NPA in the Philippines, who, in line with a declared communist ideology, have focused taxation efforts on the local business class (Santos and Santos 2010). Similarly, the Marxist ideological orientation of the FARC shaped its targeting of elites through taxation (Mampilly 2021: 87). Similar dynamics are common with Islamist groups and taxes on alcohol or narcotics, while ideological motivations to control behaviour can also provide motivation for groups not to tax. Indeed, groups may constrain revenue generation to ensure ideological coherence. For example, the $\mathrm{KIO} / \mathrm{A}$ has opted to forgo the potential profits that could be derived from either illicit opium cultivation, trade, or taxation of the production and trade of narcotics in order to limit the harms of drug use - as well as to undermine the Myanmar state and its alleged involvement in the illicit heroin and opium trade (Dan, Maran, Sadan, Meehan and Goodhand 2021; Weigand 2020). Meanwhile, in 2012 when Ansar Dine and its allies controlled Timbuktu, custom duties and taxes were banned under the claim that custom duties and tariffs were illicit under sharia law (Strazzari 2015: 7). However, these tactics also may have been an attempt to win over support and business from traders, traffickers, and smugglers, with the group claiming that 'trading has returned to normal; more goods are available than before, and at lower prices' (ibid.).

Taxation can also be a way to operationalise ideological positions vis-à-vis the state. The Liberation Tigers of Tamil Eelam (LTTE), for example, levied considerably higher local taxes on individuals working in government professions (Mampilly 2011; Stokke 2006). Rebels knew that government employees could pay, while levying more burdensome taxes on government employees had the dual effect of imposing a financial sanction on government employees and diverting government revenues to their cause (Mampilly 2011: 115). The Naxalite insurgency in India followed a similar pattern of levying taxes only on government contractors, using the revenue to finance their activities (Suykens 2015).

In many instances, however, ideology appears to drive armed groups' framing of taxation more than it drives the actual practice of it. The Taliban use the terminology of ushr and zakat loosely, for instance, which allows them to maximise the revenue they can extract based on prevailing local conditions while still holding on to some form of Islamic justification for doing so. Al-Shabaab is even more imprecise with its adaptation of Islamic taxes. While the entirety of its zakat collection was initially (if only very briefly) distributed to the poor, alShabaab has continued to collect zakat, using its own interpretation of how much should be levied, ${ }^{10}$ and without necessarily redistributing that revenue for welfare purposes. ${ }^{11}$ Meanwhile, while AQIM has imposed 30 per cent tax rates at checkpoints on some

10 Al-Shabaab's zakat is set at 2.5 per cent of the monetary value of a business (as assessed by the group) before profit. As the Hiraal Institute (2018: 2) note, 'This is contrary to Islamic law, which requires that Zakah is paid as a percentage of what one has at the end of the financial year, after deducting all liabilities. This has led some of the more idealistic AS members to demand that their salaries be paid from the Zakah and not by taxes collected by the Finance Office.'

$11 \quad$ As described by the Hiraal Institute (2018: 1), 'The first head of the Zakawaat office was Sheikh Fuad, who notoriously paid all the collected Zakah to the poor, leading to his immediate dismissal after his first year in the job; Al-Shabab had a different interpretation on how the Zakah should be used, and afterwards only a small fraction was given to the poor.' 
religiously forbidden goods, like cocaine, it has been argued that these levies are primarily motivated by profit rather than ideology (Fanusie and Entz 2017; Larémont 2011).

As these examples suggest, ideological preferences are not fixed and may evolve in response to material circumstances. In other words, the need to generate revenue also shapes rebel ideology or the instrumentalisation of ideology, insofar as ideology can be sidelined or used to enable revenue raising activities (Dishman 2001; Rosenthal 2008). Ideologies themselves are often littered with contradictions, while ideological framing is often used pragmatically to serve the needs of an insurgency. A by-product of this fluid relationship is that the need for resources can create uncomfortable ideological contradictions. The Taliban, for example, profit from taxing the opium trade (Mansfield 2016), leaving them open to accusations of hypocrisy from both internal and external audiences. ${ }^{12}$ Similarly, in Colombia, FARC initially prohibited drug cultivation, considering it counter-revolutionary (Rosenthal 2008: 484), before levying a ten per cent tax on coca and poppy yields and, finally, becoming immersed in the drug trade themselves (Otis 2014: 3).

\subsection{Building legitimacy}

Armed group taxation can thus be motivated and shaped by non-material factors, like ideology. Similarly, taxation and legitimacy, understood in an empirical way as voluntary obedience to social control (Weber, Henderson and Parsons 1964), are deeply entwined concepts. While many people, rather unsurprisingly, do not enjoy paying taxes and criticise certain taxation policies, it is a generally accepted right of states to tax populations. Stewart (2015: 31) suggests that "the principles and practice of taxation in successful "tax states" have evolved interdependently with the benefit and legitimacy of government'. Indeed, taxation and legitimacy were co-produced in the process of state formation in Europe, with states successfully monopolising the legitimate use of force and the legitimate right to tax (Bourdieu, Wacquant and Farage 1994; Bourdieu 2020; Elias 1994). In contemporary conflict-affected contexts, competing armed authorities, including states, armed groups, and other public authorities, such as strongmen or warlords, likewise frequently claim the legitimate use of force and the legitimate right to tax. Legitimacy considerations thus factor into the motivation of why armed groups tax. ${ }^{13}$

Legitimacy underpins the ability of armed groups to tax populations under their control. For instance, the BRN in Southern Thailand collects levies - which the group refers to as voluntary donations - in areas with a heavy Thai army presence that limits the group's ability to enforce collection coercively (Weigand 2020), indicating a degree of public support and legitimacy. Thakur and Mampilly (forthcoming) argue that the taxation practices of armed groups in Northeast India are best understood as a technology of governance, with the degree of legitimacy that armed groups have shaping the nature of revenue collection strategies. Groups with a higher degree of legitimacy use taxation in more deliberate ways to maintain or further their local support, resulting in what Levi (1988) describes as 'quasivoluntary compliance' of local populations. Meanwhile, groups with a lower degree of legitimacy have less structured approaches to taxation and, naturally, require more coercion to enforce compliance.

An armed group's interest in local legitimacy shapes not only the extent to which it is able to levy taxes but also the character of its taxation practices. Armed groups that want to construct legitimacy have to be conscious of local perceptions when demanding levies, such as views on what type of activities are locally accepted. For example, Hoffmann et al. (2016)

\footnotetext{
12 More broadly, reliance on illicit forms of finance that conflict with group ideology can undermine legitimacy and the prospects for recognition, as we discuss below. The fact that Abu Sayyaf in the Philippines generates revenue through kidnappings, including of Muslims, detracts from their ideological legitimacy (Weigand 2020).

13 Furthermore, though beyond the scope of this paper, legitimacy helps us to explain how armed groups tax and what their taxation practices look like.
} 
illustrate that the taxation practices of the Mai-Mai Kifuafua in Eastern DRC are viewed as legitimate because they respect local norms and are 'subject to a high level of negotiation with customary authorities and other local notables' (Hoffmann et al. 2016: 1451, see also Vlassenroot, Mudinga and Musamba 2021). In Southeast Asia, Weigand (2020) shows that the extent to which armed groups are concerned about and dependent on local legitimacy shapes their economic policies and practices. As discussed above, groups like the KIO/A in Myanmar's Kachin State that are concerned about their local support cannot encourage and tax opium production, at least openly, as it is viewed as harmful and destructive locally. Instead, the $\mathrm{KIO} / \mathrm{A}$ taxes what is locally accepted and commonly viewed as legal, such as vehicles, shops and other businesses, including those exporting timber and livestock to China. Meanwhile, militia groups like the former NDA-K, which relies on support from the Myanmar central state and military rather than the local population, can benefit from taxing the production of drugs.

Additionally, and perhaps counterintuitively, taxation can help armed groups build legitimacy among civilian populations by enabling public service provision and, possibly, the establishment of a form of 'tacit social contract' (Podder 2014; Terpstra and Frerks 2017) or a 'social order during wartime' (Arjona 2016). ${ }^{14}$ And, indeed, armed groups across the world provide public services financed at least in part through taxation. Using the financial resources they generate through measures such as taxation, for instance, Afghanistan's Taliban provide justice and conflict resolution (Jackson and Weigand 2020), while Myanmar's $\mathrm{KIO} / \mathrm{A}$ offers health care and education (Brenner 2015, 2018). Even if taxation is unpopular, it allows armed groups to provide services that people need and therefore expand their local support. As legitimacy enables taxation and as taxation allows for the provision of services, taxation and legitimacy can thus reinforce each other. Similarly, taxation is closely related to the regulatory functions of states and proto-states. Where taxation enables an armed group's regulatory authority and functions, it can increase the group's legitimacy as a ruler.

The idea of legitimacy being purely transactional, however, has increasingly been called into question, particularly through the notion that 'substantive' legitimacy, based on values and resulting in the belief in an actor's authority, cannot be 'bought' simply by providing public goods or services (McCullough 2019, 2020; Weigand 2015, 2017, 2022). Even when receiving useful public services from an armed group or another authority, individuals do not necessarily believe that the authority has the right to rule. Meanwhile, providing services in a way that is perceived to be unfair can undermine an authority's substantive legitimacy (Mcloughlin 2018; Weigand 2022)..$^{15}$ Nonetheless, the provision of services financed by taxation is an important aspect of governance, and can allow armed groups to build shortterm civilian support and 'instrumental' legitimacy, which can perhaps be transformed into more substantive legitimacy over time.

\subsection{Institution building}

Closely related to legitimacy, taxation represents a bureaucratic function and can thus be a means for armed groups to build state-like institutions that strengthen their legitimacy and organisational capacity, with implications beyond revenue raising. The literature on taxation and state-building makes clear that a common by-product of taxation is institution building. As Tilly shows in the case of early modern Europe, 'within limits... extraction and struggle over the means of war created the central organisational structures of the state'. This has implications for more than the ability to raise revenue; during conflict, the 'ability of government administrators to establish the routine by which revenues were collected, money

See also e.g. Mampilly 2011; Mampilly 2015; Péclard and Mechoulan 2015; Raeymaekers 2011.

This fact can provide both an opportunity and a challenge for armed groups. For instance, corruption in Afghanistan's state justice system increased support for the Taliban over many years (Jackson and Weigand 2020; Weigand 2017) However, with growing influence, bureaucratisation and reach, the Taliban justice system has faced similar problems (Human Rights Watch 2020). 
raised and supply requisitioned could make the difference between victory and humiliation' (Brewer 1989: 13). The expansion of the bureaucracy was made necessary by taxation with taxation implying a need, for instance, for institutions that can handle information gathering, enforcement, and dispute resolution - while an expansion of civilian bureaucracies made further taxation necessary (Brautigam 2008; Moore 2004; Fukuyama 2015). ${ }^{16}$

Similar institution building often arises as a result of taxation by armed groups. ${ }^{17}$ For example, in Somalia, al-Shabaab maintains a considerable 'shadow government' that enables a highly efficient and centralised taxation system, that is often seen as more effective than that of the state (Bryden 2014; S.J. Hansen 2016; Hiraal Institute 2018, 2020; Maruf and Joseph 2018; UN Monitoring Group on Somalia and Eritrea 2018; van den Boogaard and Santoro 2021). Its fiscal bureaucracy includes an intelligence branch, the Amniyaat, which enforces collection, as well as two departments, the Zakawaat Office and the Finance Office, that collect non-monetary and monetary taxes, respectively. Revenues are subsequently shared between headquarters and ministerial regional offices. This expansive bureaucracy is costly: the Hiraal Institute (2018) notes that in recent years the group's expenses have 'ballooned' as a result of 'recurring payments to hundreds of officials', including soldiers, police, and administrators, while paying its fighters and administrators to retain their loyalty is its utmost budgetary priority.

While institution building may thus sometimes be a by-product of rather than a primary motive for taxation, taxation also represents a means of centralising authority through institution building. Bureaucratic institutions often institute a degree of hierarchy, supervision, and professionalisation, while the expansion of fiscal institutions may be used as a means of extending authority and control. This centralisation of authority may be a driving motive for armed groups, with the bureaucratisation enabled by taxation serving to both institute internal discipline and to control fragmented or competing sources of authority in a particular territory. In Myanmar, for example, the Karen National Union (KNU) - the political organisation of the Karen National Liberation Army (KNLA) - has an extensive bureaucracy, with centralised institutions and a hierarchy flowing up to the centre, allowing it to institute a degree of internal discipline and control, however imperfect. ${ }^{18}$ The Finance and Revenue Department maintains detailed handbooks outlining tax procedures for its various departments, including agriculture and defence, with institutional expansion and coordination critical to its operations (Jolliffe 2016). For example, procedures for taxing farmland are included in the Agriculture Department's handbooks, with taxes and fees collected in cooperation with other relevant departments, including the Forestry Department and the Breeding and Waterways Department. Meanwhile, 'KNU basic organizations' (ibid.: 22) collect taxes at the village level, while also being responsible for organising social services, registering people for party membership, and identifying recruits (ibid.). ${ }^{19}$

Taxation enables control not just over internal bureaucracies and civilian populations, but also over potential threats and competitors to the authority of the armed group. In areas

16 Fukuyama (2015: 265) explains the cycle thusly, 'resource requirements of long-term warfare... led states to tax their citizens, create finance ministries and bureaucracies to administer the tax extraction, build administrative hierarchies to manage extensive logistical systems... all of this led to a dramatic expansion of the revenue needs of early modern European states in the $17^{\text {th }}$ and $18^{\text {th }}$ centuries, and the growth of civilian bureaucracies.'

17 This institution building drive is not, however, universal. For example, despite Abu Sayyaf's stated aim of creating an independent Islamic state in the Philippines, it has not obviously built a bureaucracy, administration, and governing institutions - in sharp contrast to other Islamic armed groups in the country, including the MILF and MNLF (Singh and Singh 2019; South and Joll 2016).

18 While the KNU tries to maintain control over this bureaucracy, it is less able to do so where its administration is weak, the KNLA has a strong presence, and insecurity is high. In these contexts, less institutionalised forms of taxation and revenue extraction are more common, with informal revenues collected by local leaders and armed members of the KNLA (Karen Human Rights Group 2018).

19 Village committees retain 10 per cent of taxes, submitting 90 per cent to the township level. Some of this is remitted to the central bureaucracy, but the majority remains in districts in order to finance the salaries of staff and military personnel, as well as social service provision. 
under its control, for instance, al-Shabaab limits local governments' revenue collection capacity, ${ }^{20}$ while also co-opting clan elders and community leaders in the collection process (Hiraal Institute 2018; van den Boogaard and Isak forthcoming). ${ }^{21}$ For example, Levy and Yusuf (2019: 10) explain,

Tribal elders play central roles as community leaders. Al-Shabaab coopts them to keep order in the areas under its control. It delegates taxation and policing to elders, who have preexisting authority among local populations. In return, al-Shabaab refrains from punishing cooperative clans, facilitates arbitration of inter-tribal disputes, and provides financial assistance to some clans.

Similarly, armed groups operating in North Kivu in the DRC have been reported to maintain the support of local chiefs and government leaders as a means of ensuring broader popular support. For instance, in order to 'uphold its relationship with surrounding communities, the ADF sent a significant proportion of the profits accumulated from its timber-related businesses [export of timber as well as taxation of timber activities] to local leaders' (ScorgiePorter 2015: 206). In at least one town where timber cutting is prevalent, this reportedly amounted to as much as half of the revenue going to Congolese officials (Scorgie-Porter 2015). More generally, the group's perceived respect for the traditional hierarchy and local leaders is thought to have increased its popular support in some regions. ${ }^{22}$ This strategy of subduing and working with local leaders led to a situation where 'the ADF was undoubtedly the authority in the space it occupied' (Scorgie-Porter 2015: 209). Similar to the ADF's strategy, the FDLR also reportedly pays off both government officials and local chiefs though they otherwise do not share their taxes from markets, traders, industries, and mining with anyone (Romkema 2007: 44).

\subsection{Legibility and control of civilian populations}

Enabled by the institution building impetus, armed group taxation can contribute to the accumulation of information about populations and support authorities' ability to control behaviour, as with state taxation. The design, planning, collection, accounting, and auditing of taxation requires an enormous amount of information about the taxed population. ${ }^{23}$ Certain taxes require intelligence on the location and number of businesses, individuals and households; their incomes; foreign and domestic transactions; and their eligibility for various exemptions. Information requirements increase with the complexity of taxation.

Consequently, taxation generates a need for a substantial amount of information, as well as a justification for the creation of an apparatus that collects and manages this information. Indeed, the history of taxation and state-building is closely connected to the history of states'

\footnotetext{
In particular, where taxpayers already have to pay taxes to al-Shabaab, some local governments report feeling limited in collecting additional revenues because of the extra burden it would imply for taxpayers - while also being physically limited in collecting taxes where there is high insecurity or a risk of retaliation by al-Shabaab (van den Boogaard and Isak forthcoming).

21 Of course, this co-optation does not necessarily imply consent by the broader civilian population or broader support for al-Shabaab. In some instances, cooperation is a strategic choice by communities in the face of violent threats.

22 In 2011, Congolese military officers estimated that the ADF 'benefits from the popular support of nearly half of the population of Beni territory' (UNSC 2011: 30), at least in part because ADF 'combatants and their family members are relatively well integrated and generally respect the traditional hierarchy in the host communities' (Romkema 2007: 29). Indeed, local chiefs assisted them in their tax collection from traders (Scorgie-Porter 2015: 197). This assistance and peaceful co-existence, however, was not universal, with some local chiefs feeling more threatened by the group and some evidence in other areas that the rebels wanted to assert great power over the chiefs and no longer pay taxes to them (Romkema 2007: 68-69). More recent violence in the region, including massacres of civilians, has further undermined its support, leading to civil society protests (Mastaki 2019).

23 Hatfield 2015 highlights, for instance, that despite the public attention to the information that the US national security apparatus holds on US citizens, 'the IRS likely has the surest legal claim to the most information about the most Americans'.
} 
and empires' efforts to make populations, economic activity and land 'legible' to the apparatus of government (Scott 1998). ${ }^{24}$

Similar to states, armed groups can then use the increased legibility of populations to support other objectives. For instance, they might be interested in gathering additional information on populations to identify areas with higher numbers of potential recruits or even to institute a draft or conscription system. They might seek out particular demographic or economic information to identify likely strongholds of support or opposition or to identify what strategies for revenue extraction might be most efficient. Unsurprisingly, the links between taxation and legibility are most obvious where armed groups have developed larger and more comprehensive administrative systems - illustrating the close relationship between information and institution building. Groups such as Hezbollah or ISIS, for example, are widely described to have developed complex administrative systems, with tax extraction enabled by administrative information collection and legibility (al-Tamimi 2015), with taxes allowing them to 'see like a state', so to say (Scott 1998). Similarly, al-Shabaab keeps a list of business owners and an estimate of their worth to facilitate tax assessment and collection, in both territory that it controls and territory that it doesn't (Hiraal Institute 2018).

Closely related to the connection between taxation and legibility are the aforementioned links between taxation and the control of populations, behaviour, and economic activity (Heer 1937). For one, taxation can be used to control the physical movement of populations and goods, as through taxes levied at roadblocks and checkpoints. As Schouten $(2019,2021)$ highlighted in his account of 'roadblock politics', roadblocks such as those operated by the M23 rebel group in Congo's North Kivu province do not only provide armed groups with an income. Instead, they also provide control over key bottlenecks of local trade routes and the associated circulations of both goods and people - providing a 'logistical form of power' and expanding common conceptions of control that focus on territory more narrowly.

Similarly, and closely linked to the discussion of ideology and legitimacy above, armed groups may use taxation as a means of controlling populations and the economy through the sanction of particular behaviour, such as trading with or selling to out-groups. For example, Revkin (2020) describes the use of border taxes by ISIS as designed to disincentivise civilians leaving the territory (and to benefit from them staying), outlining an illustrative use of a tax in order to control a population. Similarly, civilians were encouraged to enlist into armed service by making those who refused to enlist pay a 'tax in lieu of jihad' (Revkin 2020). In the case of the eastern DRC, Hoffmann et al. (2016) also observe how taxes play a wider symbolic role for establishing relationships of control between citizens and armed groups in a context where territorial boundaries are often complex, noting that 'taxes establish mutual obligations between armed groups and residents. They are constitutive for the establishment of the boundaries of the political community and public authority. In this sense they are constitutive of both citizenship and jurisdiction.' Civilians are not without agency in this process. They often attempt, sometimes successfully, to influence and shape the nature of armed group control and policies at the local level. For instance, Jackson (2021) illustrates how communities in Afghanistan negotiate their relationship with the Taliban, including with regard to taxation. Poor farmers often had the best leverage, using tactics, such as pleading relative poverty, to elicit sympathy and leveraging the collective power of community elders to help negotiate down insurgent taxes. In numerous cases, the Taliban relented, at least temporarily, or reduced its demands where it encountered organised, steadfast resistance.

Taxation may further be used to control the economy, including through attempts to influence consumption behaviour through taxes on goods like tobacco or sugar, as well as more

The first cadastral surveys, for example, trace their origins to the need of local rulers to increase tax yield from land, and have since been a site of contestation about legibility (Sánchez-Talanquer 2020). Legibility typically refers to states' possession of information, but also how this information is structured and aggregated in ways that make it understandable and actionable to state administrators. 
comprehensive attempts to shape economic policy and policy through measures like tax incentives. Formal state taxation is habitually analysed in the context of wider economic policy, as setting not just the space for redistribution and investment, but as being a central element in strategic industrial policy and business-state relationships. While they might not explicitly attempt import substitution industrialisation or similar strategies, armed groups still occasionally develop an active interest in regulating local economies. This can be as an element of a wider strategic engagement with the population, for example to lower prices for essential goods; in the context of armed groups' own involvement in economic enterprises, including to target firms owned by rival groups; or to strategically subsidise economic activities seen as desirable. One such example is the short-lived Armed Forces of the Congolese People (Forces Armées du Peuple Congolais, FAPC) in eastern Congo. As discussed by Titeca (2011), the group was reliant on connection with local traders in order to gain access to income from lootable goods. Consequently, the group purposefully used tax policy, including a simplified 'pre-payment system' as well as low and predictable rates, in order to attract traders, seeking to create a 'Monaco' in Eastern Congo (Titeca 2011: 52).

\subsection{Performing public authority}

While the bureaucratic and institution building enabled by taxation may thus help to further the objectives of an armed group, the very existence of a fiscal bureaucracy also serves the purpose of reinforcing groups' authority through their association with symbols of statehood. Taxation is associated with legitimate statehood; armed group taxation is consequently often highly symbolic and can be viewed as an attempt to act like a state in order to construct state-like legitimacy in the eyes of local, national and international audiences. By 'doing what states do' and using the 'symbols of statehood' through the levying of taxes on the populations under their control (Hagmann and Péclard 2010; T.B. Hansen and Stepputat 2001; Lund 2006; Hoffmann et al. 2016; Huang 2016; Mampilly 2015; Reno 2015; Tull 2003), armed groups may support claims of being legitimate de facto states.

As Hoffmann et al. (2016: 1436) note, 'taxation practices of armed groups - consciously or unconsciously - draw upon, mobilize, evoke and perform the language of stateness when they tax people.' In the context of armed group taxation, symbols of statehood often manifest through the giving of official-looking receipts. For instance, reports indicate that the Taliban's 'Department of Tax and Revenue' issues receipts for taxes levied on goods being transported through checkpoints (Kumar 2018); al-Shabaab issues official receipts for a variety of the taxes it levies, including on transiting vehicles, transported goods, farms and agricultural produces, and livestock sales (Hiraal Institute 2020; UN Monitoring Group on Somalia and Eritrea 2018); while in the CAR, the UPC issues receipts for taxes paid on the purchase and transport of livestock as well as on goods leaving the region under their control as 'customs' taxes (Jaillon et al. 2017). In some ways, therefore, the building of a fiscal bureaucracy reflects a type of isomorphic mimicry (Andrews, Pritchett and Woolcock 2017), with armed groups effectively mimicking the states with which they frequently are at war $(A$. Jackson 2018; Stokke 2006). ${ }^{25}$

In the DRC, for example, Hoffmann et al. (2016: 1434) note that armed groups' tax practices are 'based on long-standing registers of authority and practices of rule that originate in the colonial era', with taxation 'at the core of armed groups' production of public authority and citizenship'. Taxation in this context is embedded in the 'language of stateness' (T.B. Hansen and Stepputat 2001: 8), reflected through public signs, rituals and spectacles. Some Mai-Mai groups, for example, have framed themselves in relation to pre-colonial empires and consequently situate taxation as a necessary contribution to the restoration of state authority. The groups invoke 'the principle of national sovereignty' in order 'to mobilize large segments

25 Of relevance to thinking about armed group taxation, Andrews et al. (2017: 31) note that "mimicry often conflates form and function: leading to a situation where "looks like" substitutes for "does".' 
of the population to contribute monetary and in-kind taxes' (Hoffmann et al. 2016: 1447), with one such Mai-Mai group creating local revenue mobilisation units (comités de soutien), 'echoing practices of the [post-colonial] Mobutu state' (Hoffmann et al. 2016: 1447; Hoffmann 2015).

The performance of statehood may be targeted at domestic or international audiences. Internationally, taxation is not only viewed as a legitimate practice of states; the right to collect taxes is also largely limited to states. Calls for international recognition of de facto states, for instance, often justify polities' 'stateness' according to their fiscal and administrative capacity (see e.g. The Economist 2021). Hence, by collecting taxes, armed groups emphasise their claim to legitimate statehood. Attention may be paid to international audiences not only for the objective of statehood recognition, but to demonstrate support for particular ideas or global movements; indeed, 'adopting a particular approach to taxation can be a signal to an external audience, which is trying to slot an organization into various categories based on their perceived fealty to broader ideological concerns' (Mampilly 2021: 96).

Domestically, meanwhile, taxation can be a means of asserting authority over civilian populations, convincing civilians of the legitimacy of that authority, or demonstrating power and capacity in relation to the formal state. Indeed, as we discuss above, introducing taxes in a newly captured territory may be a means of normalising a new form of rule, while taxation based on a reciprocal fiscal social contract may be a means of winning the support of civilian populations. As Mampilly (2015) argues, symbolic processes can influence an armed group's relationship with civilians both by fostering greater identification and ties of legitimacy and by reinforcing civilian perceptions of the coercive power of the group, reducing its need to rely on enforcement mechanisms to ensure compliance (see also Mampilly 2021: 84-5). In line with this, Sweet (2020: 1) argues that armed groups' projection of a 'state-like image is more than a simple veneer', but further enables support and capacity to wage conflict. For example, in part because of the documentation it provides and the willingness to respond to disputes, there is evidence that some traders deliberately take transport routes under alShabaab control rather than government-controlled routes, with al-Shabaab taxation viewed as more predictable and less likely to result in double taxation (UN Monitoring Group on Somalia and Eritrea 2018). Meanwhile, in the eastern DRC, the Mai-Mai Kifuafua used 'practical and symbolic registers of authority and languages of stateness' in order to gain popular support, framing itself as a 'state within a state', with taxation justified in exchange for the security it could provide for community members (Hoffmann 2016: 1451).

At the same time, armed groups may use taxation as a means of demonstrating their equal or greater competency and legitimacy to raise taxes in relation to political opponents, such as the de jure state that they are frequently fighting. For example, in 2016, the Taliban's central leadership formally demanded a tax of 10 per cent on telecommunication companies two months after the Afghan government announced impressive new revenues from an increased tax on telecommunications operators at the same rate. An individual in the Quetta Shura, the Taliban's leadership council, justified the parallel tax by saying 'It is our right to tax you if you want us to protect your [transmission] towers around Afghanistan' (cited in Chopra 2016). The performative importance of taxation is even more striking in cases of such imitation where the revenues from new taxes are minimal or non-existent. For example, in Kunduz province, the Taliban levies charges on electricity that probably result in the group losing money, as noted above. It still levies them, however, and goes to the trouble of manufacturing bills that are in some cases 'near-replicas' of the bills produced by the stateowned electricity company, going 'to a great deal of effort to mimic official systems' (A. Jackson 2018: 23).

As noted above, requiring government officials to pay taxes is another way for armed groups to exert their authority in relation to the de jure state. For example, Stokke (2006: 1022) 
notes that in Sri Lanka the LTTE exercised 'considerable influence on state institutions and officials in the government-controlled parts of the northeast province', while in Somalia alShabaab demonstrates its authority and power by levying taxes on government officials, including top commanders of the Somali National Army that are not in direct danger from the group (Hiraal Institute 2020: 6-7). As discussed above, armed groups like the LTTE in Sri Lanka and the Naxalites in India taxed government officials and contractors more than others, thereby emphasising their own authority vis-à-vis the government. The act of levying taxes can thus reinforce the claim of armed groups that they are the only legitimate authority with a monopoly over revenue extraction. Similarly, armed groups may also attempt to impose control over external actors, including the international community. For example, armed groups such as the Taliban, ISIS and al-Shabaab have taxed international development or humanitarian assistance (see e.g. Bowden 2021). While there are clear revenue motives for doing so, these taxes also help them to illustrate groups' authority in a given region.

Meanwhile, the trappings of a fiscal bureaucracy may also be an attempt to assert sovereignty and supplement claims of statehood. For instance, in late 2019, when the Arakan Army in Myanmar announced the formation of the Rakhine People's Authority to levy taxes on businesses in order to fund its military and political operations and administer areas under its control, it framed taxation as a legitimate means of founding a new form of government that would re-establish the historic Arakan nation that had existed centuries earlier (Radio Free Asia 2020). While the new taxing authority is obviously motivated in part by revenue, observers note that 'its creation is probably more important as a demonstration of the group's de facto authority and territorial control and assertion of its legitimacy' (International Crisis Group 2020). This reflects a common strategy and motivation of other groups in the region and beyond. Similarly, the Free Aceh Movement (GAM) in Indonesia levied the 'Pajak Nanggrow', roughly translating to 'state tax' - a clear indication of the group's objectives for state-based autonomy (Aspinall 2009).

These performative acts of statehood are particularly important in the contemporary context given norms of territorial sovereignty and the limitations of state formation in the global order (e.g. Bates 2008; R. Jackson 1995; Sørensen 2001; Spruyt 2009). Indeed, building states in the early 21 st century is a very different endeavour than it was in the early modern Europe that Tilly (1985) and Olson (1993) documented. Armed groups that seek to engage in statebuilding today do so in the context of a state system that is more consolidated, territorialised, and globalised, and that has itself embraced the Weberian notion of a state as one with an established monopoly over coercion and commonly frames non-state governance as a form of disorder, insecurity and an existential threat. The nature of the post-WWII global order implies different requirements for modern would-be stationary bandits, including engagement with international norms and conventions and global narratives around autonomy and selfdetermination. ${ }^{26}$ While having the trappings of statehood may not be a sufficient condition for de facto statehood, it may at least be a necessary one.

Even with these limitations, there are a range of ways in which armed group taxation can be motivated by an interest in building relationships with civilian populations and projecting authority, thereby establishing legitimacy with both domestic and external audiences. Of course, however, and in line with the recognition of the diverse objectives of armed groups, some groups profess no explicit agenda to build a state, secede from a state or at some point hold an exclusive monopoly on the use of force, legitimate or not, in a particular

\footnotetext{
26 Most critically, it means that for many armed groups, institution building is, at least in the medium term, going to occur in a constrained sense, and in close interaction with states. The PKK in particular offers an expansive case study on these dynamics. Meanwhile, following institution building and a military offensive the Taliban successfully captured the Afghan state in August 2021.
} 
territory. ${ }^{27}$ This does not mean that these armed groups do not engage in institution building, that they do not care about building legitimacy or complex administrative structures; rather, these means may lead to ends other than de facto statehood. ${ }^{28}$ At the same time, it is important to recognise that a group's short and long-term objectives may differ, while its objectives around statehood or public authority may shift over time. ${ }^{29}$

\section{Conclusions}

As we have shown throughout this paper, armed group taxation can be motivated by more than just the opportunity to raise revenue. Specifically, armed groups can use taxation to execute ideology, build legitimacy, develop institutions, increase their control over civilian populations, and to perform and project public authority. In line with Mampilly (2021: 88), we show that 'reducing rebel taxation to a purely economic bargaining logic fails to situate it within the broader social and political contexts that many scholars of taxation and state power emphasise'. We thus contribute to debates about the role of greed in motivating armed groups in conflict, as well as to a growing literature on rebel governance (e.g. Arjona, Kasfir and Mampilly 2015; Furlan 2020). We show that taxation can enable service provision and rebel governance and can thus shape the relationships between armed groups and civilian populations and the underlying legitimacy of armed groups' authority. At the same time, we contribute to debates about the nature and boundaries of informal and formal taxation, illustrating the ways in which armed group taxation intentionally imitates state taxation and can thus not simply be classified as extortion. This is in line with the idea that 'the distinction between state and non-state actors, and between state and non-state war economies, is in large part elusive' as 'the methods of wealth accumulation and their social impact... bear surprising resemblances' to state and non-state groups (Di Cosmo et al. 2021: $5)$.

While our findings contribute to theoretical understanding of armed groups, conflict, and state-building, they also raise important questions for future research. We highlight three areas in particular where we believe further research would be beneficial. First, given the complexity in delineating the distinctions between taxation and extortion, future research could usefully further explore the language used to describe taxation and the meaning that is embedded within such language. While journalistic accounts often use the terminology of 'extortion' and aid organisations often refer to the payments as 'levies' in an effort to not legitimise them, our exploration of non-revenue motives for taxation, especially those related to legitimacy and state-building, indicate that these descriptors may not always provide the full story. At the same time, the description of 'taxation' by armed groups that rely heavily on coercion or the threat of violence to collect taxes may likewise not be appropriate.

Accordingly, there is a need for greater conceptual clarity when describing revenue extraction by armed groups, with attention being paid to both how armed groups describe and taxpayers perceive the levies. Understanding civilian perspectives here will be central to better understanding the nature and legitimacy of armed group revenue extraction.

\footnotetext{
$27 \quad$ Some groups may in fact be primarily driven by economic motives, may limit their activity to supporting a political goal in a different territory, might seek to influence politics within an existing state system, to capture power within it or to change it, or might solely seek to maximise revenue.

$28 \quad$ This could include what some scholars refer to as 'hybrid political orders' (Boege, Brown and Clements 2009), with armed groups seeking to don the mantle of some state authority in the sense described by Lund's 'twilight institutions', or more explicitly following the institutional blueprint of a legal political organisation within a state, by forming a political party.

29 In the context of formal states, a fitting analogy might be separate states that still express their reunification with a neighbouring state as an overarching priority while engaging in separate institution building - such as South and North Korea or the former East and West Germany. This points to the importance of additional analysis of the potential tensions between medium and long term group objectives, while critically highlighting the importance of recognising the difficulty in analysing motivations in armed groups.
} 
Second, and building on both the 'resource curse' literature (Ross 2004; Ross 2015) and the tax and accountability literature (Moore 2004; Prichard 2015), future research could usefully explore whether and how variation in tax practices relates to the non-tax revenues available to an armed group and how such practices influence the relationship with civilian populations (Sarkar and Sarkar 2017). If armed groups receive revenues from natural resources, state sponsors, or the diaspora, do they retain non-revenue incentives to tax ${ }^{30}$ At the same time, the contexts in which armed groups choose not to tax requires greater exploration. For instance, as noted above, when AQIM took control of Timbuktu, Mali in 2012, it abolished customs, duties, tools and tariffs as an apparent means of building favour with local residents; likewise, the AQIM-offshoot MUJAO abolished taxes in areas it governed, reportedly to gain favour with local populations (Fanusie and Entz 2017). What do such instances of non-taxation imply for the relationship between armed groups and local populations and how do they relate to the availability of non-tax revenue sources?

Third, building on the broader literature linking conflict to taxation and state-building (Centeno 1997, 2002; Tilly 1992), future research should explore the relationship between conflict intensity and taxation. Taking into consideration the fiscal imperatives of war-making and the link between territorial control and capacity to tax, how does the nature of conflict affect armed group taxing practices, including the type, rate, and target of levies and the language that is used by groups to describe and justify their taxes? Exploring this question has particularly important implications for understanding relationships with civilian populations, social order during wartime, and state-building processes.

The findings, perspectives and questions discussed here likewise have important policy implications. Crucially, this paper has illustrated that armed groups do not only tax to maximise revenue generation. Policymakers need to consider the political dimensions that underpin many of the economic decisions of armed groups, including their taxation policies. While groups such as the Taliban tax international organisations to illustrate their authority, the Houthis in Yemen retreated from their plan of taxing international aid organisations after the extent to which it would strain their relationship with the international community became clear (BBC 2020). This shows that international actors can have leverage on armed group taxation strategies, with high political costs for armed groups having the potential to outweigh the financial benefits in some cases. As many armed groups aspire to statehood, they aim to be seen to perform functions of legitimate public authority. Humanitarian organisations could exert influence over armed groups by taking their statehood claims seriously. Beyond reminding armed groups of their obligations as parties to a conflict under international humanitarian law, humanitarian organisations could point out to armed groups that states typically do not tax charitable and aid organisations. ${ }^{31}$

Furthermore, it would be wrong for policymakers to assume that the payment of taxes to armed groups necessarily indicates either coercion or support for this group. Many armed groups, just like states, have successfully established institutions that normalise the payment of levies and even use taxation to build local legitimacy without explicit coercion.

Nonetheless, armed group taxation, like all taxation, is typically still backed by the potential of coercion. Hence, the payment of taxes by civilians to an armed group does not necessarily indicate support for the group either. Due to the often-structured nature of armed group taxation, civilians frequently keep the receipts issued by armed groups, enabling them to

30 While some have considered the relationship between financing sources and armed group relationships with civilian populations, these have, to the best of our knowledge, excluded an explicit exploration of armed group taxation.

31 According to Art 61 of the Geneva Convention on the protection of civilians (1949) 'Such consignments shall be exempt in occupied territory from all charges, taxes or customs duties unless these are necessary in the interests of the economy of the territory. The Occupying Power shall facilitate the rapid distribution of these consignments. All Contracting Parties shall endeavour to permit the transit and transport, free of charge, of such relief consignments on their way to occupied territories. 
prove that they have paid the necessary levies on their business or goods. While such receipts are often used as evidence for the support of an armed group by opposing governments - for instance, by the army in Myanmar that uses such receipts as evidence to arrest people on the basis of the Unlawful Associations Act (India Act XIV 1908) that criminalises contact with armed groups such as the $\mathrm{KIO} / \mathrm{A}$ - they in fact often only illustrate the pragmatic behaviour of civilians who want to avoid being taxed repeatedly. As described by the Hiraal Institute (2020: 6), 'payment to [al-Shabaab] has little to do with recognizing the legitimacy of the group but more to do with the practicality of real life, which makes it impossible to conduct business in areas where the group has operational presence' (Hiraal Institute 2020: 6).

While this paper has shown the diversity of armed group taxation strategies, underpinned by different drivers and motives, more research needs to be done to unpack these dynamics and to develop a more structured understanding of the taxation strategies of different types of armed groups. More work to expand both the breadth of cases as well as the depth of information on armed groups' taxation should be prioritised. The findings of such research could help policymakers that engage with armed groups to mediate peace agreements, to advocate for human rights and to deliver aid into areas under armed groups' control or influence. 


\section{Appendix}

\section{List of the cases included in this review}

\begin{tabular}{|c|c|c|}
\hline Name of Group & Country & Years Active \\
\hline Al-Shabaab & Somalia & 2007-Present \\
\hline The Barisan Revolusi Nasional Melayu Patani (BRN) & Southern Thailand & 1963-Present \\
\hline Cammora & Italy & $\begin{array}{l}\text { 17th Century- } \\
\text { Present }\end{array}$ \\
\hline Fources Nouvelles de Cote d'Ivoire (FNI) & Cote d'Ivoire & $2002-2011$ \\
\hline The Provisional Irish Republican Army (IRA) & Northern Ireland & $1969-2005$ \\
\hline Shining Path/Communist Party of Peru & Peru & 1969-1992 \\
\hline Taliban, Islamic Emirate of Afghanistan & Afghanistan; Pakistan & 1994-Present \\
\hline Islamic State of Iraq and Syria (ISIS/IS/ISIL/Daesh) & Western Iraq; Eastern Syria & 1999-Present \\
\hline Hay-at Tahrir al-Sham (HTS) & Syria & 2017-Present \\
\hline Kurdistan Worker's Party (PKK) & Turkey & 1978-Present \\
\hline Seleka & Central African Republic & 2012-Present \\
\hline Union for Peace in the Central African Republic (UPC) & Central African Republic & 2014-Present \\
\hline al-Qaida in the Islamic Maghreb (AQIM) & Algeria; Mauritania; Mali & 2007-Present \\
\hline Jama'at Nasr al-Islam wal Muslimin (JNIM) & Algeria; Mauritania; Mali & 2017-Present \\
\hline Movement for Oneness and Jihad in West Africa (MUJAO) & Algeria; Mauritania; Mali & $2011-2015$ \\
\hline Hezbollah & Lebanon & 1982-Present \\
\hline Hamas & Palestine; Israel & 1987-Present \\
\hline Revolutionary Armed Forces of Colombia (FARC) & Colombia & $1964-2016$ \\
\hline National Liberation Army (ELN) & Colombia & 1966-Present \\
\hline Liberation Tigers of Tamil Eelam (LTTE) & Sri Lanka & $1976-2009$ \\
\hline Tehrik-i-Taliban (TTP) & Pakistan & 2007-Present \\
\hline New Democratic Army - Kachin (NDA-K) & Myanmar & $1989-2009$ \\
\hline Ta'ang National Liberation Army & Myanmar & 1992-Present \\
\hline Karen National Liberation Army (KNLA) & Myanmar & 1949-Present \\
\hline Kachin Independence Organization/Army (KIO/A) & Myanmar & 1960-Present \\
\hline Karen National Union (KNU) & Myanmar & 1947-Present \\
\hline Shan State Army - North & Myanmar & 1964-Present \\
\hline Shan State Army - South & Myanmar & 1996-Present \\
\hline United Wa State Army & Myanmar & 1989-Present \\
\hline Arakan Army (AA) & Myanmar & 2009-Present \\
\hline Gerakan Aceh Merdeka (GAM) (Free Aceh Movement) & Indonesia & $1976-2005$ \\
\hline
\end{tabular}




\begin{tabular}{|l|l|l|}
\hline $\begin{array}{l}\text { Communist Party of the Philippines/New People's Army } \\
\text { (CPP-NPA) }\end{array}$ & Philippines & $1969-$ Present \\
\hline Abu Sayyaf Group & Philippines & 1991 -Present \\
\hline Moro Islamic Liberation Front (MILF) & Philippines & $1977-$ Present \\
\hline Moro National Liberation Front (MNLF) & Philippines & $1972-$ Present \\
\hline Bangsamoro Islamic Freedom Fighters (BIFF) & Philippines & $2010-$ Present \\
\hline Allied Democratic Forces (ADF) & Uganda; DRC & $1996-$ Present \\
\hline $\begin{array}{l}\text { National Union for the Total Independence of Angola } \\
\text { (UNITA) }\end{array}$ & Angola & $1966-2002$ \\
\hline Lord's Resistance Army (LRA) & DRC; Uganda & $1987-$ Present \\
\hline M23 & DRC & $2012-2013$ \\
\hline National Congress for the Defence of the People (CNDP) & DRC & $2006-2009$ \\
\hline Democratic Forces for the Liberation of Rwanda (FDLR) & DRC; Rwanda & $2000-$ Present \\
\hline Movement for the Liberation of the Congo (MLC) & DRC & $1998-2006$ \\
\hline Rally for Congolese Democracy (RCD) & DRC & $1998-2003$ \\
\hline $\begin{array}{l}\text { Communist Party of India (Maoist) - People's Liberation } \\
\text { Guerilla Army }\end{array}$ & India & $2000-$ Present \\
\hline Mara Salvatrucha (MS)-13 & El Salvador; USA & $1980-$ Present \\
\hline Janjaweed & Sudan & $\begin{array}{l}\text { Mid-1980s- } \\
\text { Present }\end{array}$ \\
\hline
\end{tabular}




\section{References}

Acharya, A., Bukhari, S.A.A.S. and Sulaiman, S. (2009) 'Making Money in the Mayhem: Funding Taliban Insurrection in the Tribal Areas of Pakistan', Studies in Conflict \& Terrorism 32.2: 95-108

Ahmad, A. (2017) Jihad and Co.: Black Markets and Islamist Power, Oxford University Press

Albert, K.E. (2020) 'Institutions of the Weak: Rebel Institutions and the Prospects of Peace after Civil War', PhD thesis, University of Rochester

al-Tamimi, A. (2015) 'The Evolution in Islamic State Administration: The Documentary Evidence', Perspectives on Terrorism 9.4: 117-129

Andrews, M., Pritchett, L. and Woolcock, M. (2017) Building State Capability: Evidence, Analysis, Action, Oxford University Press

Aspinall, E. (2009) 'Combatants to Contractors: The Political Economy of Peace in Aceh', Indonesia 87: 1-34

Arjona, A. (2016) Rebelocracy, Cambridge University Press

Arjona, A., Kasfir, N. and Mampilly, Z. (eds.) (2015) Rebel Governance in Civil War, Cambridge University Press

Bates, R.H. (2008. When Things Fell Apart: State Failure in Late-century Africa, Cambridge University Press

BBC (2020) 'Yemen's Houthis Step Back on Threat to Tax Aid', BBC News, 14 February

Berti, B. (2016) 'Rebel Politics and the State: Between Conflict and Post-conflict, Resistance and Co-existence', Civil Wars, 18.2: 118-136

Boege, V., Brown, M.A. and Clements, K.P. (2009) 'Hybrid Political Orders, Not Fragile States', Peace Review, 21.1: 13-21

Bourdieu, P. (2020) On the State: Lectures at the Collège de France 1989-1992, Cambridge and Medford: Polity Press

Bourdieu, P., Wacquant, L.J.D. and Farage, S. (1994) 'Rethinking the State: Genesis and Structure of the Bureaucratic Field', Sociological Theory, 12.1: 1

Bowden, M. (2021) 'After Geneva - the New Challenges and Risks Facing NGOs and Civil Society in Afghanistan', Lessons for Peace Afghanistan Blog, ODI, 30 March

Braithwaite, V.A. (2009) Defiance in Taxation and Governance: Resisting and Dismissing Authority in a Democracy, Edward Elgar

Brautigam, D.A. (2008) 'Introduction: Taxation and State-building in Developing Countries', in D. Brautigam, O.H. Fjeldstad and M. Moore (eds.) Taxation and State-building in Developing Countries: Capacity and Consent, Cambridge University Press: 1-33

Brenner, D. (2018) 'Inside the Karen Insurgency: Explaining Conflict and Conciliation in Myanmar's Changing Borderlands', Asian Security 14.2: 83-99 
Brenner, D. (2015) 'Ashes of Co-optation: From Armed Group Fragmentation to the Rebuilding of Popular Insurgency in Myanmar', Conflict, Security \& Development 15.4: 337-358

Brewer, J. (1989) The Sinews of Power: War, Money, and the English State, 1688-1783, 1st American ed., Knopf

Bryden, M. (2014) The Reinvention of Al-Shabaab: A Strategy of Choice or Necessity? Center for Strategic and International Studies

Centeno, M.A. (2002) Blood and Debt: War and the Nation-state in Latin America, Pennsylvania State Univ. Press

Centeno, M.A. (1997) 'Blood and Debt: War and Taxation in Nineteenth-Century Latin America', American Journal of Sociology, 102.6: 1565-1605

Chakravarti, S. (2014) Clear, Hold, Build: Hard Lessons of Business and Human Rights in India, HarperCollins Publishers

Chopra, A. (2016) Afghan Taliban Flex Muscles with New Telecom "Tax", AFP, Yahoo News, 28 January, http://news.yahoo.com/afghan-taliban-flex-muscles-telecom-tax064416382.html

Collier, P. and Hoeffler, A. (2005) 'Resource rents, governance, and conflict', The Journal of Conflict Resolution 49.4: 625-633

Collier, P. and Hoeffler, A. (2004) 'Greed and Grievance in Civil War', Oxford Economic Papers 56.4: 563-595

Croissant, A. and Barlow, D. (2007) 'Following the Money Trail: Terrorist Financing and Government Responses in Southeast Asia', Studies in Conflict \& Terrorism 30.2: 131156

Dan, S.L., Maran, J.H.P., Sadan, M., Meehan, P. and Goodhand, J. (2021) 'The Pat Jasan Drug Eradication Social Movement in Northern Myanmar, Part One: Origins \& Reactions', International Journal of Drug Policy 89

Darling, L.T. (1996) Revenue-raising and Legitimacy: Tax Collection and Finance Administration in the Ottoman Empire, 1560-1660, E.J. Brill

de Waal, A. (1997) Famine Crimes: Politics and the Disaster Relief Industry in Africa, Villiers Publications

Di Cosmo, N., Fassin, D. and Pinaud, C. (2021) 'Introduction: Revisiting Non-states War Economies', in N. Di Cosmo, D. Fassin and C. Pinaud (eds.) Rebel Economies: Warlords, Insurgents, Humanitarians, Maryland: The Rowman \& Littlefield Publishing Group: 19-34

Dishman, C. (2001) 'Terrorism, Crime, and Transformation', Studies in Conflict \& Terrorism 24.1: 43-58

The Economist (2021) 'Somaliland Deserves International Recognition', 8 May, https://www.economist.com/leaders/2021/05/08/somaliland-deserves-internationalrecognition 
Elias, N. (1994) The Civilizing Process, Blackwell

Fanusie, Y J. and Entz, A. (2017) Al-Qaeda in the Islamic Maghreb: Financial Assessment, Center on Sanctions \& Illicit Finance.

Fukuyama, F. (2015) Political Order and Political Decay: From the Industrial Revolution to the Globalization of Democracy, paperback ed., Profile Books

Furlan, M. (2020) 'Understanding Governance by Insurgent Non-State Actors: A MultiDimensional Typology', Civil Wars 22.4: 478-511

Hagmann, T. and Péclard, D. (2010) 'Negotiating Statehood: Dynamics of Power and Domination in Africa: Negotiating Statehood', Development and Change 41.4: 539-562

Hansen, S.J. (2016) Al-Shabaab in Somalia: The History and Ideology of a Militant Islamist Group, Oxford University Press

Hansen, T.B. and Stepputat, F. (eds.) (2001) States of Imagination: Ethnographic Explorations of the Postcolonial State, Duke University Press

Harper, M. (2020) Somalia Conflict: Al-Shabab "Collects More Revenue than Government", BBC World Service News, 26 October, https://www.bbc.com/news/world-africa54690561

Hatfield, M. (2015) 'Taxation and Surveillance: An Agenda', University of Washington School of Law Digital Commons

Heer, C. (1937) 'Taxation as an Instrument of Social Control', American Journal of Sociology 42.4: 484-492

Hiraal Institute (2020) A Losing Game: Countering al-Shabaab's Financial System, Hiraal Institute

Hiraal Institute (2018) The AS Finance System, Hiraal Institute

Hoffmann, K. (2015) 'Myths Set in Motion: The Moral Economy of Mai Mai Governance', in A. Arjona, N. Kasfir and Z. Mampilly (eds.), Rebel Governance in Civil War, Cambridge University Press: 158-179

Hoffmann, K., Vlassenroot, K. and Marchais, G. (2016) 'Taxation, Stateness and Armed Groups: Public Authority and Resource Extraction in Eastern Congo', Development and Change 47.6: 1434-1456

Hofmann, C. and Schneckener, U. (2011) 'Engaging Non-state Armed Actors in State- and Peace-building: Options and Strategies', International Review of the Red Cross 93.883: 603-621

Huang, R. (2016) ‘Rebel Diplomacy in Civil War’, International Security 40.4: 89-126

Human Rights Watch (2020) 'You Have No Right to Complain'. Education, Social Restrictions, and Justice in Taliban-Held Afghanistan, Human Rights Watch

International Crisis Group (2020) An Avoidable War: Politics and Armed Conflict in Myanmar's Rakhine State, Report No. 307, 9 June, 
https://www.crisisgroup.org/asia/south-east-asia/myanmar/307-avoidable-war-politicsand-armed-conflict-myanmars-rakhine-state

Jackson, A. (2021) Negotiating Survival: Civilian-Insurgent Relations in Afghanistan, Hurst Jackson, A. (2018) Life Under the Taliban Shadow Government, Research Report, Overseas Development Institute

Jackson, A. and Weigand, F. (2020) Rebel Rule of Law: Taliban Courts in the West and North-west of Afghanistan, Briefing/Policy Paper, Overseas Development Institute

Jackson, R. (1995) 'International Community Beyond the Cold War', in G.M. Lyons and M. Mastanduno (eds.), Beyond Westphalia: State Sovereignty and International Intervention, Johns Hopkins University Press

Jaillon, A., Schouten, P. and Kalessopo, S. (2017) The Politics of Pillage: The Political Economy of Roadblocks in the Central African Republic, International Peace Information Service

Jolliffe, K. (2016) Ceasefires, Governance, and Development: The Karen National Union in Times of Change, The Asia Foundation

Karen Human Rights Group (2018) 'Looting, Extortion, and Arbitrary Taxation', in Foundation of Fear: 25 Years of Villagers' Voices from SouthEast Myanmar, https://khrg.org/2018/02/17-1-t1-ch5/chapter-5-looting-extortion-and-arbitrary-taxation

Keatinge, T. (2014) 'The Importance of Financing in Enabling and Sustaining the Conflict in Syria (and Beyond)', Perspectives on Terrorism 8.4

Keen, D. (2008) Complex Emergencies, Polity

Kumar, R. (2018) From Road Tax to Courts: The Taliban's Attempts at State-building, Al Jazeera

Larémont, R.R. (2011) 'Al Qaeda in the Islamic Maghreb: Terrorism and Counterterrorism in the Sahel', African Security 4.4: 242-268

Le Billion, P. (2006) Fuelling War: Natural Resources and Armed Conflict, Routledge

Levi, M. (1988) Of Rule and Revenue, Los Angeles and London: University of California Press

Levy, I. and Yusuf, A. (2019) 'How Do Terrorist Organizations Make Money? Terrorist Funding and Innovation in the Case of al-Shabaab', Studies in Conflict \& Terrorism, 123

Lister, C. (2014) Profiling the Islamic State, Brookings Doha Center Analysis Paper No. 13, Brookings Doha Center

Lund, C. (2006) 'Twilight Institutions: Public Authority and Local Politics in Africa', Development and Change 37.4: 685-705

Mampilly, Z. (2021) 'Rebel Taxation: Between the Moral and Market Economy', in N. Di Cosmo, D. Fassin and C. Pinaud (eds.), Rebel Economies: Warlords, Insurgents, Humanitarians, Maryland: The Rowman \& Littlefield Publishing Group 
Mampilly, Z. (2015) 'Performing the Nation-state: Rebel Governance and Symbolic Processes', in A. Arjona, N. Kasfir and Z. Mampilly (eds.), Rebel Governance in Civil War, Cambridge University Press: 74-97

Mampilly, Z. (2011) Rebel Rulers: Insurgent Governance and Civilian Life During War, Cornell University Press

Mampilly, Z. and Thakur, S. (forthcoming) 'Rebel Taxation: Extortion or a Technology of Governance? Telling the Difference in India's Northeast'

Mansfield, D. (2016) A State Built on Sand: How Opium Undermined Afghanistan, Hurst and Company

Maruf, H. and Joseph, D. (2018) Inside al-Shabaab: The Secret History of al-Qaeda's Most Powerful Ally, Indiana University Press

Mastaki, F. (2019) 'Massacres à Beni: Après des Journées Ville Morte, la Société Civile Décrète la Désobéissance Fiscale', Media Congo, 28 July, https://www.mediacongo.net/article-actualite-

54563_massacres_a_beni_apres_des_journees_ville_morte_la_societe_civile_decrete la_desobeissance_fiscale.html

Metelits, C. (2009) Inside Insurgency, New York, NY: New York University Press

McCullough, A. (2020) Reconstructing Our Understanding of the Link Between Services and State Legitimacy, Secure Livelihoods Research Consortium

McCullough, A. (2019) Why Services Won't Always Buy Legitimacy: Everyday Experiences of the State in Swat, Pakistan, Secure Livelihoods Research Consortium

McDermott, J. (2017) 'The FARC's Riches: Up to $\$ 580$ Million in Annual Income', Insight Crime, Investigation and Analysis of Organized Crime, 6 September

Mcloughlin, C. (2018) 'When the Virtuous Circle Unravels: Unfair Service Provision and State De-legitimation in Divided Societies', Journal of Intervention and Statebuilding 12.4: 527-544

Moore, M. (2004) 'Revenues, State Formation, and the Quality of Governance in Developing Countries', International Political Science Review 25.3: 297-319

Nellemann, C., Henriksen, R., Pravettoni, R., Schlingemann, M., Shaw, M. and Reitano, T. (2018) World Atlas of Illicit Flows, INTERPOL, RHIPTO, and the Global Initiative Against Transnational Crime

Okello, D.H. (2020) 'US Concerned by al-Shabaab Finance Accumulation', Chimp Reports, 24 November, https://chimpreports.com/us-concerned-by-al-shabaab-financeaccumulation/

Olson, M. (1993) 'Dictatorship, Democracy, and Development', The American Political Science Review 87.3: 567-576

Otis, J. (2014) The FARC and Colombia's Illegal Drug Trade, Wilson Center LatinAmerican Program 
Péclard, D. and Mechoulan, D. (2015) Rebel Governance and the Politics of Civil War, Swiss Peace Foundation

Podder, S. (2014) 'Mainstreaming the Non-state in Bottom-up State-building: Linkages Between Rebel Governance and Post-conflict Legitimacy', Conflict, Security and Development 14.2: 213-243

Prichard, W. (2015) Taxation, Responsiveness and Accountability in Sub-Saharan Africa, Cambridge University Press

Quimpo, N.G. (2014) "Revolutionary Taxation" and the Logistical and Strategic Dilemmas of the Maoist Insurgency in the Philippines', Journal of Asian Security and International Affairs 1.3: 263-287

Radio Free Asia (2020) 'Arakan Army Collects Taxes, Polices Streets in Parts of Myanmar's War-Torn Rakhine State', Radio Free Asia, 20 July, https://www.rfa.org/english/news/myanmar/arakan-army-07202020093940.html

Raeymaekers, T. (2011) Forced Displacement and Youth Employment in the Aftermath of the Congo War: From Making a Living to Making a Life, MICROCON Research Working Paper No. 38

Reno, Wi. (2015) 'Predatory Rebels and Governance: The National Patriotic Front of Liberia, 1989-1992', in A. Arjona, N. Kasfir and Z. Mampilly (eds.), Rebel Governance in Civil War, Cambridge University Press: 265-285

Rettberg, A. and Ortiz-Riomalo, J.F. (2016) 'Golden Opportunity, or a New Twist on the Resource-Conflict Relationship: Links Between the Drug Trade and Illegal Gold Mining in Colombia', World Development 84: 82-96

Revkin, M.R. (2020) 'What Explains Taxation by Resource-rich Rebels? Evidence from the Islamic State in Syria', Journal of Politics 82.2

Richani, N. (2013) Systems of Violence: The Political Economy of War and Peace in Colombia, (2nd ed.), State University of New York Press

Romkema, H. (2007) Opportunities and Constraints for the Disarmament \& Repatriation of Foreign Armed Groups in the Democratic Republic of Congo, No. 44081, The World Bank

Rosenthal, J.A. (2008) 'For-Profit Terrorism: The Rise of Armed Entrepreneurs', Studies in Conflict \& Terrorism 31.6: 481-498

Ross, M. (2004) 'What Do We Know about Natural Resources and Civil War?', Journal of Peace Research 41.3: 337-356

Ross, M. L. (2015) 'What Have We Learned About the Resource Curse?', The Annual Review of Political Science, 18: 239-259

Sabates-Wheeler, R. and Verwimp, P. (2014) 'Extortion with Protection: Understanding the Effect of Rebel Taxation on Civilian Welfare in Burundi', The Journal of Conflict Resolution 58.8: 1474-1499

San-Acka, B. (2015) Dangerous Companions: Cooperation Between States and Nonstate Armed Groups (NAGs), v.04/2015, nonstatearmedgroups.ku.edu.tr 
Sánchez-Talanquer, M. (2020) 'One-Eyed State: The Politics of Legibility and Property Taxation', Latin American Politics and Society 62.3: 65-93

Sanín, F.G. and Wood, E.J. (2014) 'Ideology in Civil War: Instrumental Adoption and Beyond', Journal of Peace Research 51.2: 213-226

Santos, S.M. and Santos, P.V.M. (2010) Primed and Purposeful: Armed Groups and Human Security Efforts in the Philippines, Small Arms Survey

Sarkar, R. and Sarkar, A. (2017) 'The Rebels' Resource Curse: A Theory of InsurgentCivilian Dynamics', Studies in Conflict \& Terrorism 40.10: 870-898

Schouten, P. (2021) Roadblock Politics: The Origins of Violence in Central Africa, Cambridge, United Kingdom; New York, NY: Cambridge University Press

Schouten, P. (2019) 'Roadblock Politics in Central Africa', Environment and Planning D: Society and Space 37.5: 924-941

Scorgie-Porter, L. (2015) 'Economic Survival and Borderland Rebellion: The Case of the Allied Democratic Forces on the Uganda-Congo Border', The Journal of the Middle East and Africa, 6.2: 191-213

Scott, J. (1998) Seeing Like a State: How Certain Schemes to Improve the Human Condition Have Failed, Yale University Press

Singh, B. and Singh, J. (2019) 'From "Bandit" to "Amir" - The Rise of the Abu Sayyaf Group as a Jihadi Organization in the Philippines', Asian Politics \& Policy 11.3: 399-416

Sørensen, G. (2001) 'War and State-Making: Why Doesn't it Work in the Third World?' Security Dialogue 32.3: 341-354

South, A. and Joll, C.M. (2016) 'From Rebels to Rulers: The Challenges of Transition for Non-state Armed Groups in Mindanao and Myanmar', Critical Asian Studies, 48.2: 168-192

Spruyt, H. (2009) 'War, Trade, and State Formation', in C. Boix and S.C. Stokes (eds.), The Oxford Handbook of Comparative Politics, Oxford University Press https://doi.org/10.1093/oxfordhb/9780199566020.003.0009

Stewart, M. (2015) The Tax State, Benefit, and Legitimacy, Working Paper No. 1/2015, Tax and Transfer Policy Institute

Stokke, K. (2006) 'Building the Tamil Eelam State: Emerging State Institutions and Forms of Governance in LTTE-controlled Areas in Sri Lanka', Third World Quarterly 27.6: 10211040

Strazzari, F. (2015) Azawad and the Rights of Passage: The Role of Illicit Trade in the Logic of Armed Group Formation in Northern Mali, Norway: Norwegian Peacebuilding Resource Centre

Suykens, B. (2015) 'Comparing Rebel Rule Through Revolution and Naturalization: Ideologies of Governance in Naxalite and Naga India', in A. Arjona, N. Kasfir and Z. Mampilly (eds.), Rebel Governance in Civil War, Cambridge University Press 
Sweet, R. (2020) 'Bureaucrats at War: The Resilient State in the Congo', African Affairs 119.475: 224-250

Terpstra, N. and Frerks, G. (2017) 'Rebel Governance and Legitimacy: Understanding the Impact of Rebel Legitimation on Civilian Compliance with the LTTE Rule', Civil Wars 19.3: $279-307$

Thorndike, J. (2014) 'How ISIS Is Using Taxes to Build a Terrorist State', Forbes, 18 August, https://www.forbes.com/sites/taxanalysts/2014/08/18/how-isis-is-using-taxes-to-build-aterrorist-state/?sh $=53 f 51 \mathrm{a} 853 \mathrm{ac0}$

Tilly, C. (1993) 'Contentious Repertoires in Great Britain, 1758-1834', Social Science History 17.2: 253

Tilly, C. (1992) Coercion, Capital, and European States, AD 990-1992, rev. pbk. ed., Blackwell

Tilly, C. (1985) 'War Making and State Making as Organized Crime', in P.B. Evans, D. Rueschemeyer and T. Skocpol (eds.), Bringing the State Back In, Cambridge University Press

Titeca, K. (2011) 'Access to Resources and Predictability in Armed Rebellion: The FAPC's Short-lived "Monaco" in Eastern Congo', Africa Spectrum 46.2: 43-70

Tull, D.M. (2003) 'A Reconfiguration of Political Order? The State of the State in North Kivu (DR Congo)', African Affairs 102.408: 429-446

UN Monitoring Group on Somalia and Eritrea (2018) Letter Dated 7 November 2018 from the Chair of the Security Council Committee Pursuant to Resolutions 751 (1992) and 1907 (2009) Concerning Somalia and Eritrea Addressed to the President of the Security Council, United Nations Security Council

UNSC (2011) Letter Dated 29 November 2011 from the Chair of the Security Council Committee Established Pursuant to Resolution 1533 (2004) Concerning the Democratic Republic of the Congo Addressed to the President of the Security Council, United Nations Security Council

van den Boogaard, V. and Santoro, F. (2021) Explaining Informal Taxation and Revenue Generation: Evidence from South-central Somalia, ICTD Working Paper 118, Brighton: Institute of Development Studies

van den Boogaard, V. and Beach, R. (Forthcoming) Tax and Governance in the Context of Scarce Revenues: Implications of Inefficient Tax Collection in Rural West Africa, ICTD Working Paper, Brighton: Institute of Development Studies

van den Boogaard, V. and Isak, N.N. (Forthcoming) The Political Economy of Taxation in Somalia: Historical Legacies, Informal Institutions, and Political Settlements, ICTD Working Paper, Brighton: Institute of Development Studies

Vlassenroot, K., Mudinga, E. and Musamba, J. (2021) 'Navigating Social Spaces: Armed Mobilization and Circular Return in Eastern DR Congo', Journal of Refugee Studies 33.4: $832-852$

Walsh, J., Conrad, J. and Whitaker, B. (2018) 'Funding Rebellion: The Rebel Contraband Dataset', Journal of Peace Research 55.5: 699-707 
Weber, M., Henderson, A.M., and Parsons, T. (1964) Max Weber: The Theory of Social and Economic Organization, New York: Free Press, Collier Macmillan

Weigand, F. (2022) Waiting for Dignity: Legitimacy and Authority in Afghanistan, New York: Columbia University Press

Weigand, F. (2020) Conflict and Transnational Crime: Borders, Bullets and Business in Southeast Asia, Edward Elgar Publishing

Weigand, F. (2017) 'Afghanistan's Taliban - Legitimate Jihadists or Coercive Extremists?', Journal of Intervention and Statebuilding 11.3: 359-381

Weigand, F. (2015). Investigating the Role of Legitimacy in the Political Order of Conflict-torn Spaces (No. 04/15; Security in Transition), LSE

Weinstein, J. (2007) Inside Rebellion: The Politics of Insurgent Violence, Cambridge: Cambridge University Press

$\mathrm{Xu}, \mathrm{Y}$. and Xu, X. (2016) 'Taxation and State-building: The Tax Reform Under the Nationalist Government in China, 1928-1949', Accounting, Organizations and Society, 48: 17-30 